\title{
Phytoplankton dynamics in the Congo River
}

\author{
JEAN-PIERRE DESCY* ${ }^{*}$, FRANÇOIS DARCHAMBEAU ${ }^{\dagger}$, THIBAULT LAMBERT $^{\dagger}$, \\ MAYA P. STOYNEVA-GAERTNER*, STEVEN BOUILLON ${ }^{\S}$ AND ALBERTO V. BORGES ${ }^{\dagger}$ \\ *Research Unit in Organismal Biology (URBE), University of Namur, Namur, Belgium \\ †Unité d'Océanographie Chimique, Université de Liège, Liège, Belgium \\ ${ }^{\star}$ Department of Botany, University of Sofia St. Kl. Ohridski, Sofia, Bulgaria \\ ${ }^{\S}$ Department of Earth \& Environmental Sciences, KU Leuven, Leuven, Belgium
}

\section{SUMMARY}

1. We report a dataset of phytoplankton in the Congo River, acquired along a $1700-\mathrm{km}$ stretch in the mainstem during high water (HW, December 2013) and falling water (FW, June 2014). Samples for phytoplankton analysis were collected in the main river, in tributaries and one lake, and various relevant environmental variables were measured. Phytoplankton biomass and composition were determined by high-performance liquid chromatography analysis of chlorophyll $a(\mathrm{Chl} a)$ and marker pigments and by microscopy. Primary production measurements were made using the ${ }^{13} \mathrm{C}$ incubation technique. In addition, data are also reported from a 19-month regular sampling (bi-monthly) at a fixed station in the mainstem of the upper Congo (at the city of Kisangani). 2. Chl a concentrations differed between the two periods studied: in the mainstem, they varied between 0.07 and $1.77 \mu \mathrm{g} \mathrm{L}{ }^{-1}$ in HW conditions and between 1.13 and $7.68 \mu \mathrm{g} \mathrm{L}^{-1}$ in FW conditions. The relative contribution to phytoplankton biomass from tributaries (mostly black waters) and from a few permanent lakes was low, and the main confluences resulted in phytoplankton dilution. Based on marker pigment concentration, green algae (both chlorophytes and streptophytes) dominated in the mainstem in HW, whereas diatoms dominated in FW; cryptophytes and cyanobacteria were more abundant but still relatively low in the FW period, both in the tributaries and in the main channel.

3. Daily integrated production measured in the mainstem $(n=15)$ varied between 64.3 and $434.1 \mathrm{mg} \mathrm{C} \mathrm{m}^{-2}$ day $^{-1}$ in FW conditions and between 51.5 and $247.6 \mathrm{mg} \mathrm{C} \mathrm{m}^{-2}$ day $^{-1}$ in HW. Phytoplankton biomass in the Congo River mainstem was likely constrained by hydrological factors (accumulation due to increased retention time during FW, dilution by increased discharge during $\mathrm{HW}$ ), even though increased nutrient availability in the FW period might have also stimulated phytoplankton production.

4. In contrast to other tropical river systems where connectivity with the floodplain and the presence of natural lakes and man-made reservoirs play a prominent role in the recruitment of phytoplankton to the main river, our results show that phytoplankton growth in the Congo River can take place in the main channel, with hydrological processes allowing maintenance of phytoplankton biomass even during HW.

Keywords: diatoms, green algae, large tropical river, physical control, potamoplankton

\section{Introduction}

Most studies on potamoplankton, i.e. the assemblage of suspended algae in flowing water, have been conducted in temperate lowland rivers, starting at the end of the 19th century with the first comprehensive reports on the presence and often substantial amounts of suspended algae in river waters (review by Welch, 1952). These early reports highlighted the role of physical factors in controlling growth and losses of algae during downstream transport, a view which was largely confirmed afterwards (e.g. Reynolds, 1988; Reynolds \& Descy, 
2 J.-P. Descy et al.

1996). The origin of this plankton was discussed by several authors, but even though riverine phytoplankton always contains a variable contribution of benthic forms brought into suspension (tychoplankton), inocula of true planktonic taxa from tributaries and retention/accumulation zones (so-called hydrological 'dead zones' by Reynolds, Carling \& Beven, 1991 and Reynolds, 2006) are needed for the development of cell populations in the main channel. These hydrological dead zones (or retention zones) may be generated by the heterogeneity of flow across a river channel (Reynolds, 1988) or constituted by backwaters with a sufficient hydrological connection with the main channel to provide inocula of cells (Reynolds et al., 1991). In retention zones, phytoplankton photosynthesis may result in net production and growth of phytoplankton, as long as the ratio euphotic depth:river channel depth allows gross primary production to exceed autotrophic respiration losses. Once in the mainstem, cell populations are transported downstream and their survival depends on their capacity to offset advective losses (Reynolds, 1988) and dilution by inputs from the catchment (Descy et al., 1987). Therefore, discharge is a key factor determining transport time and suspended matter load, which influences light penetration in the water column, with mean light exposure depending on channel depth. In other words, it is the physical setting, constrained by hydrology and river morphology, that controls phytoplankton development, and algal populations are submitted to a strong selection by light and temperature: traits such as the ability to achieve net photosynthesis at low light and high specific growth rates are essential for survival and for population increase (Reynolds, 1994). Therefore, in temperate rivers, diatoms, which are well adapted to low temperature and low light, have been generally reported as dominant by biomass in rivers at all times from spring to autumn, with coccal green algae being most species rich and developing whenever conditions allow for greater light availability (Rojo, Alvarez-Cobelas \& Arauzo, 1994; Reynolds \& Descy, 1996). Besides, evidence for nutrient limitation of phytoplankton growth in rivers has been scarce (Basu \& Pick, 1996), even though measures for reducing the nutrient loading to major rivers may have resulted in effective control of phytoplankton biomass (Minaudo et al., 2015).

While it has been stated that 'tropical rivers are poorly understood compared with their temperate counterparts' (Davies, Bunn \& Hamilton, 2008), the studies conducted in the tropical and subtropical regions suggest that phytoplankton dynamics in tropical rivers obey the same rules as in temperate rivers given above, even though specific features of tropical rivers further constrain development of algal populations within the river channel. The best studied tropical rivers are South American rivers such as the Amazon (Fisher \& Parsley, 1979; Wissmar et al., 1981; Forsberg et al., 1993), but also the Uruguay (O'Farrell \& Izaguirre, 2014), Paraná (Bonetto, 1983; Garcia de Emiliani, 1990) and Paraguay (Zalocar De Domitrovic, 2002; Zalocar de Domitrovic, Devercelli \& Garcia de Emiliani, 2007; Devercelli et al., 2014). The emerging general view is that, in lowland high-order rivers, phytoplankton production in river channels is 'exceedingly low' (Lewis, Hamilton \& Saunders, 1995) due to extreme light limitation, combined in black water rivers with low nutrient concentrations (Wissmar et al., 1981). In fact, in situ phytoplankton growth seems extremely low in lowland large South American rivers and appears to be actually imported from adjacent floodplain lakes, where high phytoplankton production occurs (Vasquez \& Wilbert, 1992; Melack \& Forsberg, 2001). Phytoplankton production in floodplain lakes is fuelled by nutrient input from the rising river waters at the onset of the wet season, when settling of suspended matter allows light penetration into the water column. This stresses the major role of the exchange of nutrients and organic matter between the rivers and the floodplain lakes that takes place during the wet season in most tropical catchments (Junk, Bayley \& Sparks, 1989; Neiff, 1996).

Regarding river phytoplankton dynamics, the best studied river in Africa is the Nile, where high phytoplankton biomass and production have been reported (Prowse \& Talling, 1958). However, the Nile River is a river-lake system, allowing increased retention times and recruitment from the lakes and relatively high abundance of planktonic species in the main river channel. As such, it behaves very differently from the above-mentioned South American rivers. Sub-Saharan rivers are poorly characterised with regard to phytoplankton dynamics: data have been obtained in small river networks such as rivers in Ivory Coast (Iltis, 1982; Koné et al., 2009; Ouffoue et al., 2013) and the Tana (Tamooh et al., 2012) and only in one large river, the Niger (Imevbore \& Visser, 1969; Imevbore, 1970).

Regarding the general taxonomic composition of phytoplankton assemblages, selection by turbulence and light availability, rather than by nutrient availability or grazing, is the key process shaping phytoplankton assemblages in most rivers (Reynolds, 1994). According to the review by Rojo et al. (1994), diatoms comprise the majority of species numbers in temperate rivers but are substituted in tropical rivers by desmids and coccal 
chlorophytes (when benthic species are not taken into account). In terms of biomass and abundance, diatoms often dominate in tropical rivers, with Aulacoseira granulata and other Aulacoseira taxa often reported (e.g. Garcia de Emiliani, 1990; Hötzel \& Croome, 1996). These diatoms are typical $r$ strategists (Reynolds, 1984), able to withstand the variability associated with variations of flow and able to achieve net growth within the time frame imposed by downstream transport and low retention time. Coccal green algae, unicellular and colonial, are also present. They may even be the most important group in terms of abundance and diversity when water transparency and depth allow greater light availability (e.g. in the upper section of the Paraguay River; Zalocar de Domitrovic et al. 2014) than in river sections with high turbidity, where low light adaptation is an absolute requirement for growth and survival (Kilham, Kilham \& Hecky, 1986). Other taxonomic groups are also reported, but they become significant only in particular conditions, for instance where substantial interactions take place between the river and the floodplain and backwaters, or with reservoirs.

This study presents data from the Congo River, the second most important river in the world in terms of catchment size and freshwater discharge, covering a 1700-km transect from Kisangani to Kinshasa (Fig. 1). The objectives of this article are to examine phytoplankton longitudinal dynamics in the river mainstem during two contrasting hydrographic conditions (high and falling water) and to identify the factors controlling phytoplankton development. We used marker pigment analyses coupled with identification of the dominant algal species by microscopy and primary production measurements. Phytoplankton primary production is a marginal component of overall carbon flows in tropical rivers that are dominated by inputs from land and from wetlands (macrophytes and flooded forest), as shown in the Amazon (Abril et al., 2014). However, phytoplankton provides organic matter with a high nutritional value compared with more refractory and $\mathrm{N}$ and $\mathrm{P}$ poor organic matter of terrestrial origin. As such, phytoplankton has been shown to be important in sustaining pelagic food webs in tropical rivers including fish (Araújo-Lima et al., 1986; Forsberg et al., 1993; BeneditoCecilio et al., 2000) that can sustain an important economic activity and a source of animal protein for the local populations.

\section{Methods}

\section{Study site and sampling}

The Congo River (Fig. 1) is the second largest river in the world in terms of discharge $\left(1457 \mathrm{~km}^{3}\right.$ year $\left.^{-1}\right)$ and

Fig. 1 Location of sampling stations during two cruises (December 2013 and June 2014) in the Congo River at the scale of the whole basin overlain on elevation. Inset: Location of the Congo River basin in Africa. Map was generated with ArcGIS $^{\circledR}$ using publically available spatial datasets.

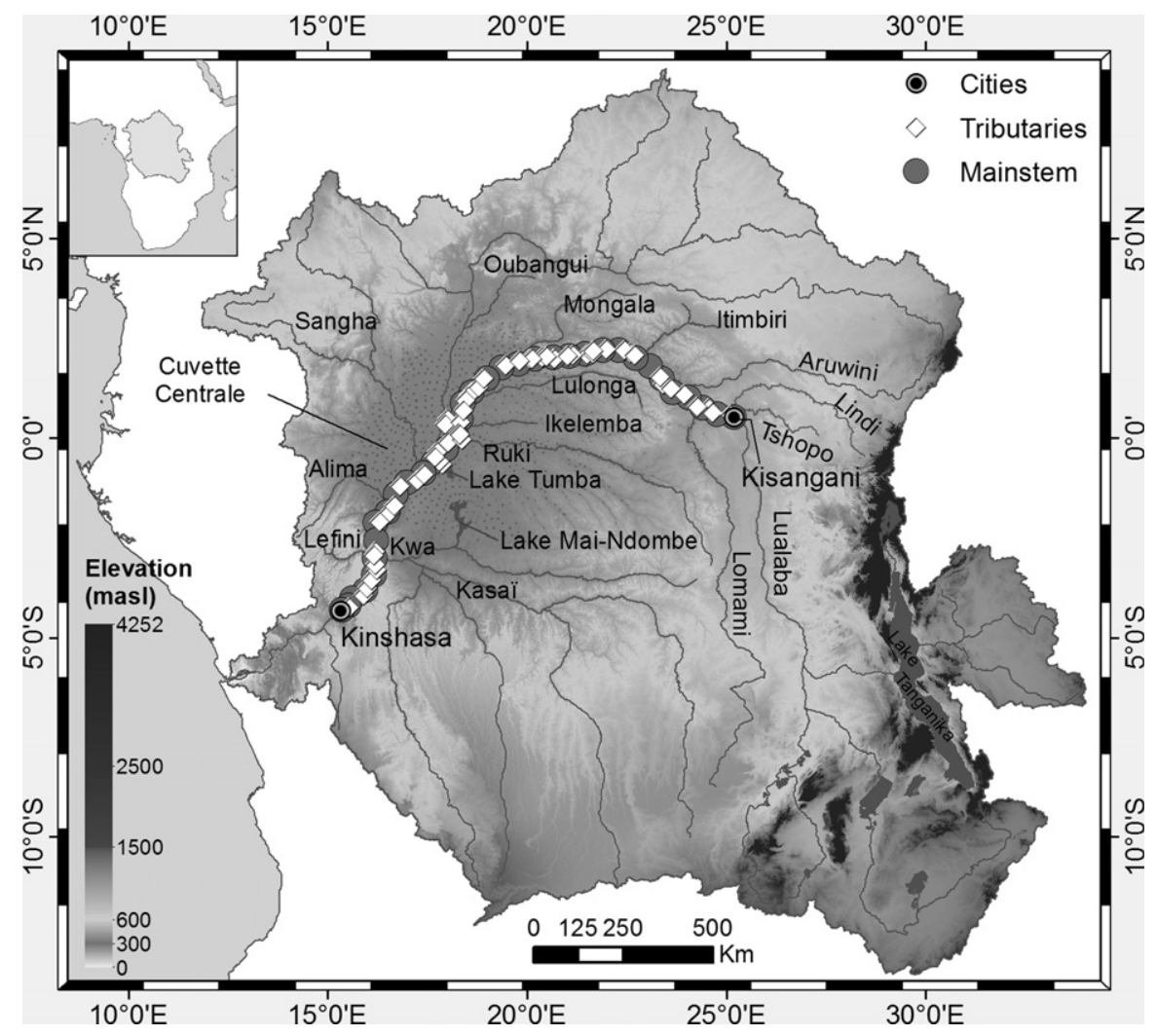

(C) 2016 John Wiley \& Sons Ltd, Freshwater Biology, doi: 10.1111/fwb.12851 
drainage basin $\left(3.75\right.$ million $\left.\mathrm{km}^{2}\right)$. Flooded areas in the Congo basin largely consist of flooded forest (Bwangoy et al., 2010), and these are mostly permanently flooded unlike the Amazon floodplains that are seasonally flooded. In addition, there are no temporary floodplain lakes but only a handful of relatively large permanent lakes (Lake Mai-Ndombe, $2300 \mathrm{~km}^{2}$; Lake Tumba, $765 \mathrm{~km}^{2}$ ). Floating macrophytes (mainly hippo grass, Vossia cuspidata) commonly occur along channel edges and within channels and form large meadows in streams, rivers and the mainstem, in all types of waters (white and black). The water height variations in the Congo mainstem are small (3-4 m), because the Congo basin straddles on the equator: the dry season on the northern part of the basin is compensated by the rainy season on the southern part of the basin, and vice versa, leading to a regulation of seasonal water height variations (Runge, 2008).

Two sampling campaigns were carried out, in the high water (HW) period, in December 2013 (75 sites), and in the falling water (FW) period in June 2014 (89 sites). The sampling was carried out in the Congo River mainstem and in tributaries, as well as in the outlet of one of the two main lakes (Lake Tumba). A few additional samples were collected on the lower stretch of the mainstem downstream of the confluence with the Kasai River in May 2015 (FW period). Despite large difference in discharge, the water height in the Congo River mainstem did not differ much between the two main campaigns (Fig. 2 and Table 1). In addition, a temporal survey, with fortnightly sampling of the Congo River, was carried out at Kisangani from November 2012 to May 2014.

Water temperature, conductivity, $\mathrm{O}_{2}$ and $\mathrm{pH}$ were measured in situ with a YSI ProPlus CTD calibrated using standard protocols. As cross-section CTD casts at several sites did not show any variation of $\mathrm{pH}, \mathrm{O}_{2}$, temperature and conductivity with depth, vertical

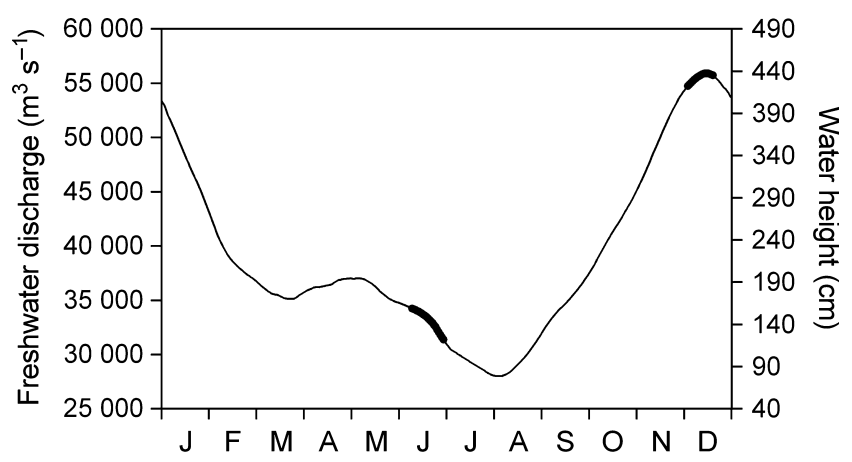

Fig. 2 Average freshwater discharge $\left(Q\right.$ in $\left.\mathrm{m}^{3} \mathrm{~s}^{-1}\right)$ of the Congo River at Kinshasa and corresponding water height at the gauging station, for the period 2003-13. Timing of the two cruises is indicated by thicker lines. homogeneity of the water column was assumed. Secchi depth was measured with a Secchi disk and water column depth was measured with a portable probe. Water was collected just below the surface in 5-L plastic bottles kept in the dark until further processing within $30 \mathrm{~min}$ (at most) of collection. Phytoplankton samples were collected with a $28-\mu \mathrm{m}$ mesh plankton net and preserved in 20-mL plastic bottles with Lugol's iodine.

The vertical light attenuation coefficient (Ke in $\mathrm{m}^{-1}$ ) was calculated from simultaneous measurements of surface irradiance with a Li-Cor LI-190 Quantum Sensor and underwater PAR measurements with a submersible Li-Cor LI-193SA Spherical Quantum Sensor (Kirk, 1994). The average light to which phytoplankton was exposed was calculated according to Riley (1957) taking into account river depth and vertical light extinction at the site of primary production measurement.

\section{Particulate and dissolved matter analyses}

Samples for total suspended matter (TSM) were obtained by filtering a known volume of water on precombusted $\left(4 \mathrm{~h}\right.$ at $500{ }^{\circ} \mathrm{C}$ ) and pre-weighed glass fibre filters ( $47 \mathrm{~mm} \mathrm{GF} / \mathrm{F}, 0.7 \mu \mathrm{m}$ nominal pore size) and airdried. These were later oven-dried prior to weighing to determine TSM load. Samples for the determination of particulate organic carbon (POC), particulate nitrogen (PN) and particulate phosphorus (PartP) were collected from a known volume of water on pre-combusted $25 \mathrm{~mm}$ GF/F filters $(0.7 \mu \mathrm{m}$ nominal pore size). The filtrate from the TSM filtrations was further filtered on 0.2$\mu \mathrm{m}$ polyethersulfone syringe filters (16532-Q; Sartorius, Goettingen) for dissolved organic carbon (DOC) (40-mL glass vials with polytetrafluoroethylene-coated septa, poisoned with $\mathrm{H}_{3} \mathrm{PO}_{4}$ ), coloured dissolved organic matter (CDOM) (20-mL amber glass vials with PTFE-coated septa) and inorganic nutrients $\left(\mathrm{NO}_{3}{ }^{-}, \mathrm{NH}_{4}{ }^{+}\right.$, dissolved $\mathrm{Si}$ and soluble reactive phosphorus - SRP) (20-mL PET vials, frozen at $-20{ }^{\circ} \mathrm{C}$ ).

The 25-mm filters for POC and PN were decarbonated with $\mathrm{HCl}$ fumes for $4 \mathrm{~h}$, re-dried and packed in Ag cups. POC and PN were determined on an elemental analyser - isotope ratio mass spectrometer (EA-IRMS; ThermoFinnigan DeltaV Advantage, ThermoFischer Scientific, Waltham) using the thermal conductivity detector signal as described by Bouillon et al. (2012). PartP was analysed by spectrophotometric determination of phosphate after digestion with potassium persulfate and boric acid (Valderrama, 1981). DOC was analysed on an Aurora1030 TOC analyser (OI Analytical, College Station) coupled to a Delta V Advantage 
Table 1 Average values and range of the variables relevant to phytoplankton ecology, for the mainstem Congo River and tributaries during high water and low water conditions. POC, particulate organic carbon; DOC, dissolved organic carbon; TSM, total suspended matter; SRP, soluble reactive phosphorus; PartP, particulate phosphorus.

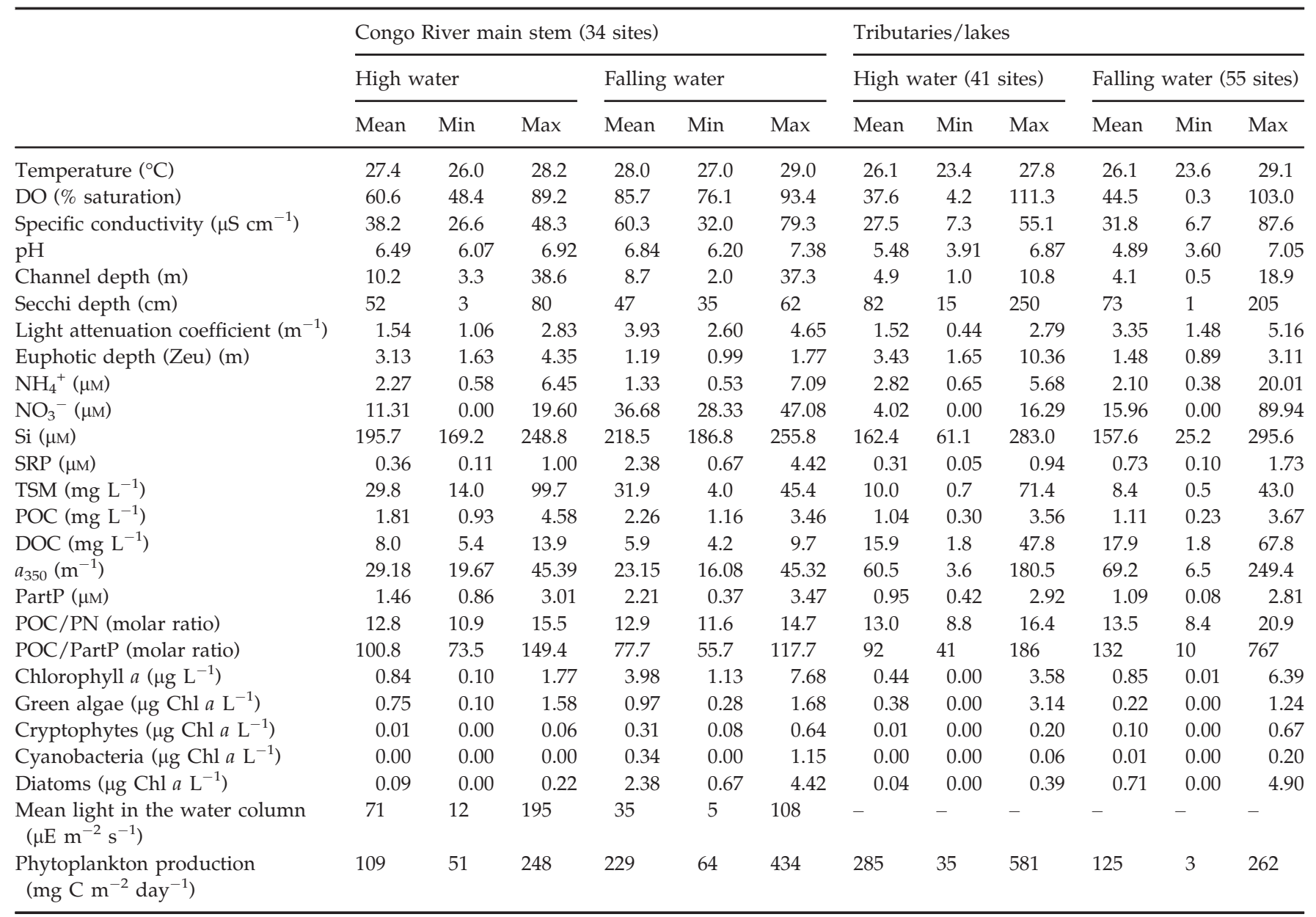

IRMS, with a precision better than $\pm 5 \%$. Absorbance was recorded on a UV/Vis $650 S$ spectrophotometer (Perkin-Elmer, Waltham, MA) using a 1-cm quartz cuvette. Absorbance spectra were used to report CDOM as the absorption coefficient at $350 \mathrm{~nm}\left(a_{350}\right)$. Details on data acquisition and corrections can be found in Lambert et al. (2015). $\mathrm{NO}_{3}{ }^{-}$and $\mathrm{NH}_{4}{ }^{+}$concentrations were estimated by spectrophotometry, using the dichloroisocyanurate-salicylate-nitroprussiate colorimetric method for $\mathrm{NH}_{4}^{+}$(Westwood, 1981), the sulfanilamide colorimetric after vanadium reduction method for $\mathrm{NO}_{3}{ }^{-}$ (American Public Health Association, 1998). SRP was determined by spectrophotometry using the ammonium molybdate-potassium antimonyl tartrate method (American Public Health Association, 1998). Si was measured with inductively coupled plasma mass spectrometry (Agilent 7700x, Santa Clara). The detection limits were $0.30,0.15,0.03$ and $8.0 \mu \mathrm{mol} \mathrm{L}{ }^{-1}$ for $\mathrm{NH}_{4}{ }^{+}, \mathrm{NO}_{3}{ }^{-}$, SRP and $\mathrm{Si}$, respectively.

\section{Phytoplankton analyses}

Pigments were analysed by high-performance liquid chromatography (HPLC) after acetone extraction (90\%) of the material filtered on Macherey-Nagel $47 \mathrm{~mm}$ diameter GF-5 filters. Filters were frozen $\left(-20^{\circ} \mathrm{C}\right)$, and within a few days, the extractions were carried out in 5 -mL acetone $(90 \%)$ and a $1-\mathrm{mL}$ extracts subsamples were kept in a portable deep-freezer until transport to Belgium. Chl $a$ and marker pigments were determined according to Descy et al. (2005), using a HPLC system (Waters, Milton) equipped with a Waters 996 PDA detector and a Water 470 fluorescence detector. The contribution of phytoplankton classes was calculated using CHEMTAX (Mackey et al., 1996), with input ratio matrices defined from microscopic examination of net samples (see below), allowing to verify the presence of diatoms, green algae (chlorophytes and streptophytes), cyanobacteria, cryptophytes, chrysophytes, dinoflag- 
6 J.-P. Descy et al.

ellates and euglenophytes. Owing to the low concentrations of pigment in the HW samples, only a few markers were used for assessing the biomass of the main phytoplankton classes: fucoxanthin (diatoms and chrysophytes), lutein and chlorophyll $b$ (green algae), alloxanthin (cryptophytes) and zeaxanthin (cyanobacteria and green algae). For the FW samples, more marker pigments were used, including neoxanthin and violaxanthin (green algae), myxoxanthophyll (cyanobacteria type 2; Wright \& Jeffrey, 2006), diadinoxanthin and diatoxanthin (diatoms), and chlorophyll $c 1-c 2$ (diatoms and cryptophytes).

Phytoplankton samples were examined at the microscope (Leitz Laborlux S, Leitz, Oberkochen and Motic BA 400, Motic, Wetzlar) for identification to species level whenever possible. We are aware that these samples may be biased towards the largest phytoplankton taxa, which were retained by the net. Therefore, the microscope data were used here for assessing taxa frequency of occurrence, and for all quantitative phytoplankton assessments, we used biomass estimates at the class level derived from processing the marker pigments concentrations with CHEMTAX.

\section{Primary production}

The primary production rate was determined from photosynthesis-irradiance incubations using $\mathrm{H}^{13} \mathrm{CO}_{3}{ }^{-}$as a tracer for incorporation of dissolved inorganic carbon (DIC) into biomass. A solution was prepared with $500 \mathrm{~mL}$ of surface water spiked with $\mathrm{NaH}^{13} \mathrm{CO}_{3}$. Subsamples of the spiked solution were preserved in triplicate in $12 \mathrm{~mL}$ Exetainer vials (Labco, Lampeter) and poisoned with a saturated solution of $\mathrm{HgCl}_{2}$, for the determination of the $\delta^{13} \mathrm{C}$-DIC value. Eight $50-\mathrm{mL}$ polycarbonate flasks were filled with the spiked solution and were placed into a floating incubator providing a range from 0 to $90 \%$ of natural light energy and incubated in situ around mid-day for $c .2 \mathrm{~h}$ just below the surface. Incident light was monitored by a LI-190SB quantum sensor (Li-Cor, Lincoln) during daytime (5-min interval acquisition) for the entire duration of the cruises. The incubation was stopped by adding neutral formaldehyde and water was filtered on pre-combusted MachereyNägel GF5 filters (25 mm diameter). Filters were rinsed with $\mathrm{HCl} 0.1 \mathrm{~N}$ and preserved dry. For the analysis of $\delta^{13} \mathrm{C}$-DIC, a 2-mL helium (He) headspace was created, and $\mathrm{H}_{3} \mathrm{PO}_{4}$ was added to convert all DIC species to $\mathrm{CO}_{2}$. After overnight equilibration, part of the headspace was injected into the He stream on the above-mentioned EA-IRMS. Given the high ${ }^{13} \mathrm{C}$-enrichments, the obtained $\delta^{13} \mathrm{C}$ data were not corrected for isotopic equilibration between gaseous and dissolved $\mathrm{CO}_{2}$. The $\delta^{13} \mathrm{C}$-POC was determined on the above-mentioned EA-IRMS using an internally calibrated acetanilide and sucrose (IAEA-C6) to calibrate the $\delta^{13} \mathrm{C}$-POC (for the natural abundance data).

The specific photosynthetic rate in an individual bottle $i, P_{i}$ (in $\mu \mathrm{g} \mathrm{C} \mathrm{L}^{-1} \mathrm{~h}^{-1}$ ) was calculated following Dauchez, Legendre \& Fortier (1995) based on the initial and final $\delta^{13} \mathrm{C}$-POC values and $\delta^{13} \mathrm{C}$-DIC of the spiked incubated solution, and considering that isotopic discrimination is negligible (Legendre \& Gosselin, 1996), at most 2.5\% according to Hama et al. (1983). For each experiment, the maximum specific photosynthetic rate $P_{\mathrm{m}}$ (in

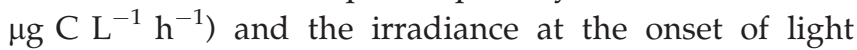
saturation $I_{k}\left(\mu \mathrm{E} \mathrm{m}^{-2} \mathrm{~s}^{-1}\right)$ were determined by fitting $P_{i}$ to the irradiance gradient provided by the incubator $I_{i}$ $\left(\mu \mathrm{E} \mathrm{m} \mathrm{m}^{-2} \mathrm{~s}^{-1}\right)$, using the following equation:

$$
P_{i}=2 P_{\mathrm{m}}\left[\frac{I_{i} / 2 I_{k}}{1+\left(I_{i} / 2 I_{k}\right)^{2}}\right]
$$

which is the Vollenweider's equation with $a=1$ and $n=1$, allowing for photoinhibition (Vollenweider, 1965), with $P_{i}$ the photosynthetic rate in bottle $i$ during the incubation, and with $I_{i}$ the corresponding mean light during the incubation. Fitting was performed using the Gauss-Newton algorithm for nonlinear least squares regression with TATISTICA software (StaSoft, Tulsa).

Daily depth-integrated primary production (mg C m ${ }^{-2}$ day $^{-1}$ ) was calculated according to Kirk (1994) using the following equation:

$$
P(z, t)=2 P_{\mathrm{m}}\left[\frac{I(z, t) / 2 I_{k}}{1+\left(I(z, t) / 2 I_{k}\right)^{2}}\right]
$$

where $P(z, t)$ is the photosynthesis at depth $z$ and time $t$, and $I(z, t)$ is the underwater light determined from Ke and surface irradiance recorded every $5 \mathrm{~min}$, and assuming a vertically homogenous $\mathrm{Chl} a$ profile. Assuming that short-term incubations provide an estimate which is close to gross primary production (GPP), we calculated water column daily respiration ( $R$,

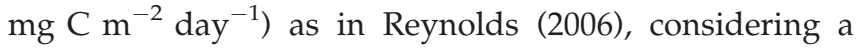
respiration rate of $0.16 \mathrm{mg} \mathrm{C} \mathrm{mg} \mathrm{Chl} a \mathrm{~h}^{-1}$ at $18^{\circ} \mathrm{C}$ (based on Lopez-Sandoval et al., 2014), a $Q_{10}$ of 2 for adjusting for river temperature, a constant respiration rate over $24 \mathrm{~h}$, and the whole river depth at the study sites. Subtracting R from GPP provided net primary production estimates, which in turn provided estimates of phytoplankton growth rate. Community growth rate was calculated using a C:Chl $a$ ratio of 40 , according to 
Harris (1986). This is an estimate of the maximal growth rate, not taking into account mortality, sedimentation and grazing losses, nor possible nutrient limitation.

\section{Statistical and multivariate analyses}

A principal component analysis (PCA) was performed on scaled variable using the prcomp function in the $\mathrm{R}$ software ( $R$ Development Core Team, 2008). Physical and chemical data from the mainstem were used as the variables for the PCA, with the objective of determining their correlation to chlorophyll $a$ and to explore the biogeochemical and ecological gradients during the two main sampling series. The following variables (see Table 1 for acronyms) were included: Rkm (River km, or distance downstream of Kisangani), Secchi depth, total suspended solids, POC, PN, PartP, $a_{350}$, SRP, nitrate, ammonia, dissolved oxygen, conductivity and $\mathrm{pH}$. A similar analysis was run for all sites, including the tributaries. Given the different units of the variables used in the PCA, data were scaled to zero-mean and unit-variance as recommended (Borcard, Gillet \& Legendre, 2011).

\section{Results}

The data are summarised in Table 1, presenting the mean and the range of the environmental data, of phytoplankton biomass and production, in the sampled tributaries and lakes, and in 34 sites along the mainstem, under both hydrological conditions (HW; FW).

\section{Physical and chemical data}

Below we focus on the variables which could influence phytoplankton development in the Congo River mainstem. The Congo River main channel is relatively shallow and its depth varies little between FW and HW (Fig. 2 and Table 1): in most sites, the depth did not exceed $10 \mathrm{~m}$ and was often lower, except in the lower part (between the mouth of the Kasai and the entrance of the Malebo pool), where the river channel is narrower and deeper (22-37 m). TSM concentrations (Fig. 3) decreased longitudinally and were higher in FW conditions, resulting in lower Secchi depth (Fig. 3) and depth of the euphotic zone (Zeu), compared to HW conditions (mean Zeu $3.1 \mathrm{~m}$ in HW versus $1.2 \mathrm{~m}$ in FW). Generally, TSM was lower in the tributaries than in the mainstem, with the exception of the Kasai River (confluence 30-km upstream of Kinshasa), and no distinct seasonal variation in the TSM of tributaries was apparent. SRP and

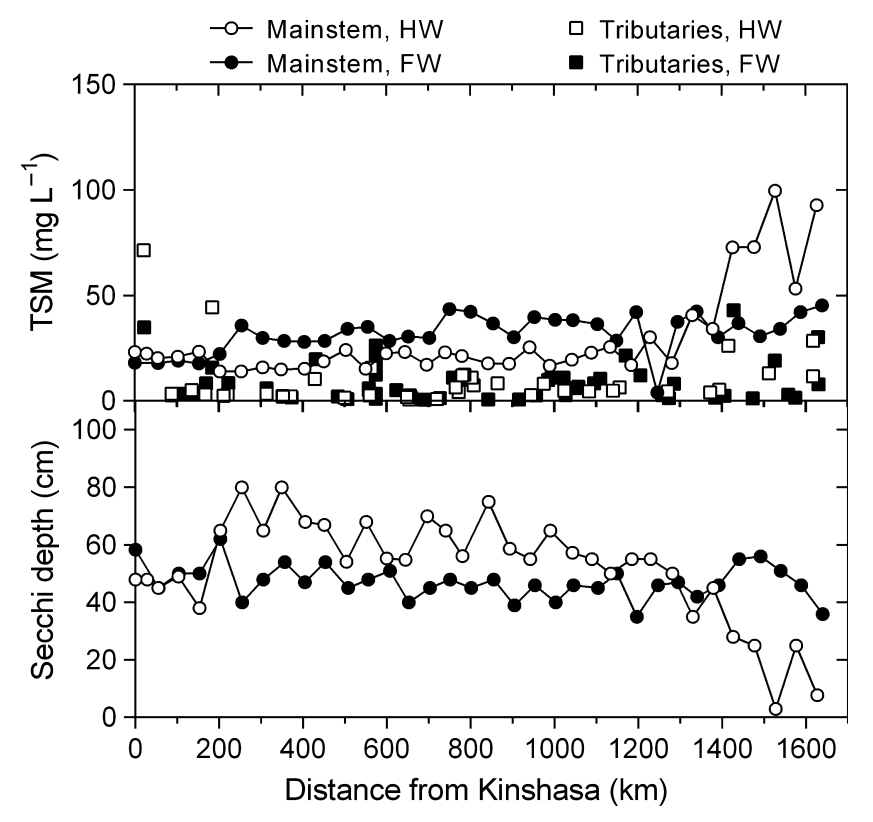

Fig. 3 Longitudinal variation of total suspended matter (TSM, $\mathrm{mg} \mathrm{L}^{-1}$ ) and of Secchi depth $(\mathrm{cm})$ in the Congo River mainstem and in the tributaries during the sampling campaigns of December 2013 (high water, HW) and June 2014 (falling water, FW).

DIN concentrations were higher in the mainstem at FW than at HW (Fig. 4). This pattern was also observed in the tributaries. The POC:PN and POC:PartP ratios (Table 1) did not vary much among sites in both hydrological conditions: the molar POC:PN averaged 12.8 (FW) and $12.9(\mathrm{HW})$, and the mean molar POC:PartP was lower in FW (78) than in HW (101). Extremely low $\mathrm{pH}$ values $(<4)$ and $\mathrm{O}_{2}$ concentrations close to zero were measured in some of the small and slow-moving tributaries draining the Cuvette Centrale (Table 1), in accordance with extremely high DOC content, and $\mathrm{CO}_{2}$ and $\mathrm{CH}_{4}$ concentrations (Borges et al., 2015a,b; Lambert et al., 2016).

\section{Phytoplankton abundance and composition}

Chlorophyll a concentrations differed between the two periods studied: in the mainstem, they varied between 0.07 and $1.77 \mu \mathrm{g} \mathrm{L}^{-1}$ in $\mathrm{HW}$ conditions and between 1.13 and $7.68 \mu \mathrm{g} \mathrm{L}^{-1}$ in FW conditions (Table 1). The range in the tributaries was even larger: $0-3.58 \mu \mathrm{g} \mathrm{L}^{-1}$ in the HW period, with maxima in the Oubangui River $\left(3.58 \mu \mathrm{g} \mathrm{L}^{-1}\right)$, in the outlet of Lake Tumba $\left(1.85 \mu \mathrm{g} \mathrm{L}^{-1}\right)$ and in the Lefini River $\left(1.71 \mu \mathrm{g} \mathrm{L}^{-1}\right)$ downstream of the Imboulou dam. In the FW period, $\mathrm{Chl} a$ in the tributaries varied between 0.02 and $6.39 \mu \mathrm{g} \mathrm{L}^{-1}$, with maxima recorded in the Oubangui River $\left(6.39 \mu \mathrm{g} \mathrm{L}^{-1}\right)$ and lake 


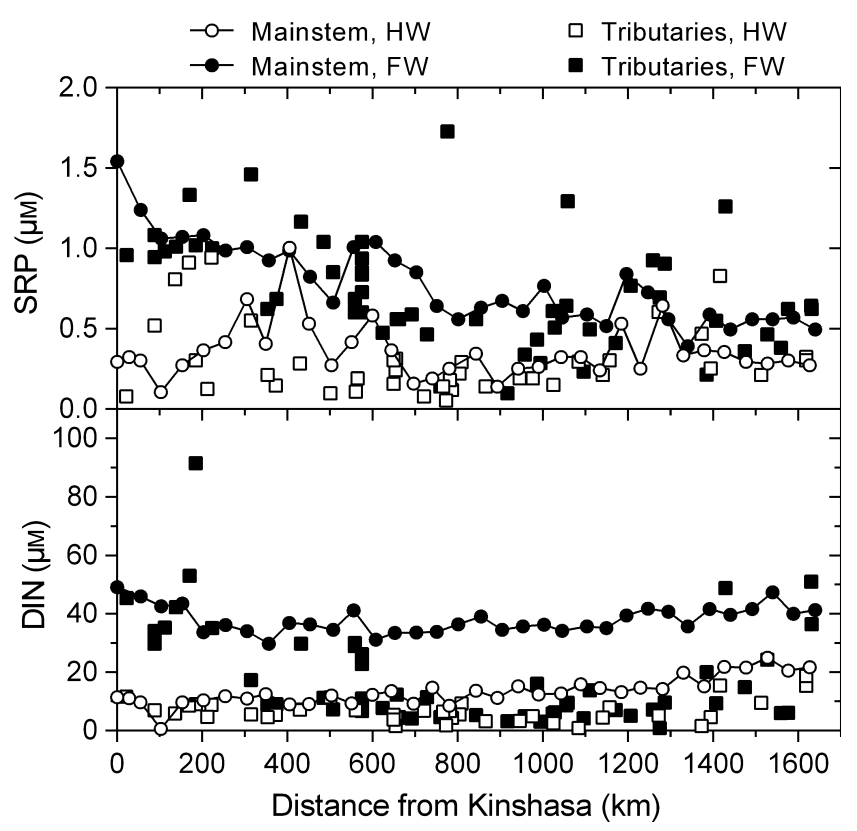

Fig. 4 Longitudinal variation of soluble reactive phosphorus (SRP, $\mu \mathrm{M})$ and of inorganic nitrogen (DIN, $\mu \mathrm{M}$ ) in the Congo River mainstem and in the tributaries during the sampling campaigns of December 2013 (high water, HW) and June 2014 (falling water, FW).

Tumba $\left(2.28 \mu \mathrm{g} \mathrm{L}^{-1}\right)$, but with higher concentrations than in HW in many tributaries, suggesting that phytoplankton development occurred throughout the Congo catchment. Substantial amounts of Chl $a$ degradation products (chlorophyllide a, phaeophytins a and phaeophorbides) were detected in most samples (on average $23 \%$ of total phorbins-a at FW), indicating the transport of dead and senescent cells among living, healthy cells and possibly of plant detritus. The longitudinal variation of $\mathrm{Chl} a$ and the contribution of the main phytoplankton groups are shown in Fig. 5. In the mainstem, Chl a exhibited a hump-shaped pattern, with a maximum between 200 and $600 \mathrm{~km}$ from Kinshasa in the HW period, and a maximum around $700 \mathrm{~km}$ from Kinshasa in the FW period. Chl $a$ in most tributaries (mostly black waters) was generally lower than in the mainstem, with few exceptions (e.g. Oubangui River and outlet of Lake Tumba in the HW period).

The difference in phytoplankton composition in the two periods is striking: both pigment data and microscopic examination of samples showed that green algae dominated in the mainstem in HW, whereas diatoms dominated in FW (Fig. 6). Green algae dominance in HW was also observed in the tributaries, where they represented on average $88 \%$ of $\mathrm{Chl} a$ (Table 1); a sample taken in a Vossia sp. patch in HW contained only green
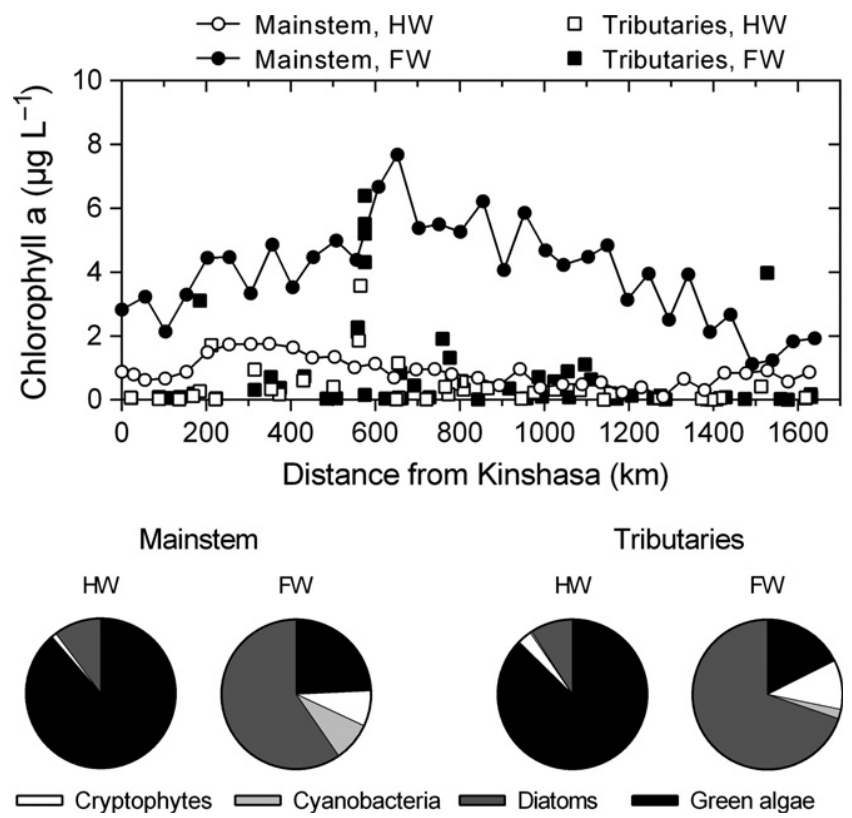

Fig. 5 Longitudinal variation of chlorophyll $a\left(\mu g \mathrm{~L}^{-1}\right)$ in the Congo River mainstem and in the tributaries during the sampling campaigns of December 2013 (high water, HW) and June 2014 (falling water, FW). The average relative contribution to chlorophyll $a$ of the main phytoplankton groups is shown below.

algae, with $98 \%$ of contribution to total Chl $a$. Cryptophytes and cyanobacteria were more abundant in the FW period, both in the tributaries and in the main channel. Overall, taxonomic diversity was greater in the FW period. The most frequent phytoplankton taxa in the Congo mainstem were Aphanocapsa spp., Aphanothece spp., Limnococcus limneticus, Planktolyngbya spp. (cyanobacteria/cyanoprokaryotes), Actinastrum rhaphidioides, Coelastrum spp., Coenochloris spp., Desmodesmus magnus, D. perforatus, Scenedesmus communis, S. oahuensis, Planktosphaeria gelatinosa (chlorophytes), Closterium spp., Hyalotheca cf. mucosa (streptophytes), Euglena spp., Strombomonas spp. (euglenophytes), Salpingoeca spp. (chrysophytes), A. granulata (including var. angustissima), A. agassizii, Cyclostephanos invisitatus, Cyclotella spp., Discotella pseudostelligera, Staurosirella spp. and Thalassiosira rudolfii (diatoms).

The PCA (Fig. 7) performed on the physical and chemical variables and Chl $a$ from the main channel (70.9\% of cumulated variance associated with the two first principal components) showed a clear discrimination between the sampling series (sites from the FW campaign in the upper part of the diagram), resulting from higher inorganic nutrient concentrations (except $\mathrm{NH}_{4}{ }^{+}$), dissolved oxygen, $\mathrm{pH}$, particulate phosphorus and $\mathrm{Chl} a$ in the FW conditions, and from higher $a_{350}$ in 


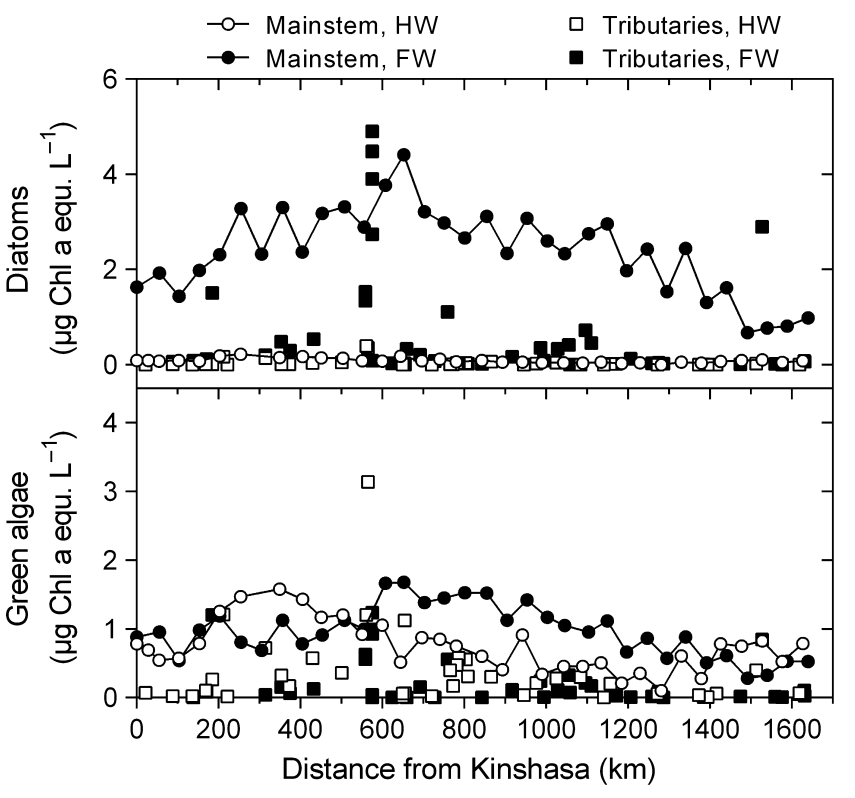

Fig. 6 Longitudinal variation of diatoms and green algae (expressed as chlorophyll $a, \mu \mathrm{g} \mathrm{L}^{-1}$ ) in the Congo River mainstem and in the tributaries during the sampling campaigns of December 2013 (high water, HW) and June 2014 (falling water, FW).

HW conditions. Within each sampling series, the sites are distributed along the first axis of the PCA, which represents a longitudinal gradient, well-marked for the HW series, depending mainly on TSM, POC, PN and Secchi depth. The PCA (Figure S1) performed on all sites, including the tributaries, essentially discriminated the tributaries from the mainstem, based on higher DOM concentration (measured by $a_{350}$ and DOC) and lower TSM, pH, POC and PN.

The temporal survey at Kisangani provided additional data, allowing to observe a strong variation of Chl a (Fig. 8) over time. Phytoplankton biomass was low (0.49-1.43 $\mu \mathrm{g} \mathrm{Chl} a \mathrm{~L}^{-1}$ ) during the HW period and increased up to $5.72 \mu \mathrm{g} \mathrm{Chl} a \mathrm{~L}^{-1}$ when discharge and TSM decreased.

\section{Phytoplankton photosynthesis and production}

The average light to which phytoplankton was exposed in the mainstem varied between 5 and $108 \mu \mathrm{E} \mathrm{m}^{-2} \mathrm{~s}^{-1}$ in FW and between 12 and $195 \mu \mathrm{E} \mathrm{m}^{-2} \mathrm{~s}^{-1}$ in HW (Table 1). Phytoplankton photosynthesis parameters were similar in the two sampling series: the mean maximal photosynthetic rate was $10 \mu \mathrm{g} \mathrm{C} \mathrm{L}^{-1} \mathrm{~h}^{-1}$ in $\mathrm{HW}$ and $11.5 \mu \mathrm{g} \mathrm{C} \mathrm{L}^{-1} \mathrm{~h}^{-1}$ in FW, with mean Ik (light at the onset of saturation of photosynthesis) of $311 \mu \mathrm{E} \mathrm{m}^{-2} \mathrm{~s}^{-1}$. Daily integrated GPP measured in the mainstem varied between 64.3 and $434.1 \mathrm{mg} \mathrm{C} \mathrm{m}^{-2}$ day $^{-1}$ in FW conditions and between 51.5 and $247.6 \mathrm{mg} \mathrm{C} \mathrm{m}^{-2}$ day $^{-1}$ in HW. Phytoplankton production was close to that of the mainstem in the main tributaries, i.e. in the rivers Tshopo (FW: $261.6 \mathrm{mg} \mathrm{C} \mathrm{m}^{-2}$ day $^{-1}$ ), Lomami (FW: $245.6 \mathrm{mg} \mathrm{C}$ $\mathrm{m}^{-2}$ day $^{-1}$ ), Oubangui (HW: $417.6 \mathrm{mg} \mathrm{C} \mathrm{m}^{-2}$ day $^{-1}$; FW: $236 \mathrm{mg} \mathrm{C} \mathrm{m}^{-2}$ day $^{-1}$ ) and Kasai (HW: $34.7 \mathrm{mg} \mathrm{C} \mathrm{m}^{-2}$ day $^{-1}$; FW: $168 \mathrm{mg} \mathrm{C} \mathrm{m}^{-2}$ day $^{-1}$ ). In both sampling series, primary production increased regularly in the Congo River (Fig. 9) between 1200 and 800 km (from Kinshasa) and dropped around the confluence with the river Oubangui, at c. $500 \mathrm{~km}$. This was related to a decrease of $\mathrm{Chl} a$ (Fig. 5) likely resulting from dilution and TSM input by this tributary, despite that it carried significant phytoplankton biomass during FW. During HW, the decrease of Chl $a$ occurred further downstream after the confluence of the Kasai River that brought high TSM to the mainstem.

Net primary production estimated for the Congo River sites $(n=30)$ varied between -442.6 and $148.4 \mathrm{mg} \mathrm{C} \mathrm{m}^{-2}$ day $^{-1}$ in FW conditions and between -64.7 and $204.0 \mathrm{mg} \mathrm{C} \mathrm{m}^{-2}$ day $^{-1}$ in HW. Community
Fig. 7 Results of a principal component analysis carried out on the physical and chemical data in the Congo River mainstem, from the sampling campaigns of December 2013 (high water, HW) and June 2014 (falling water, FW). The dots are the sampling sites; their shading depends on the distance from Kinshasa. See Table 1 for acronyms.

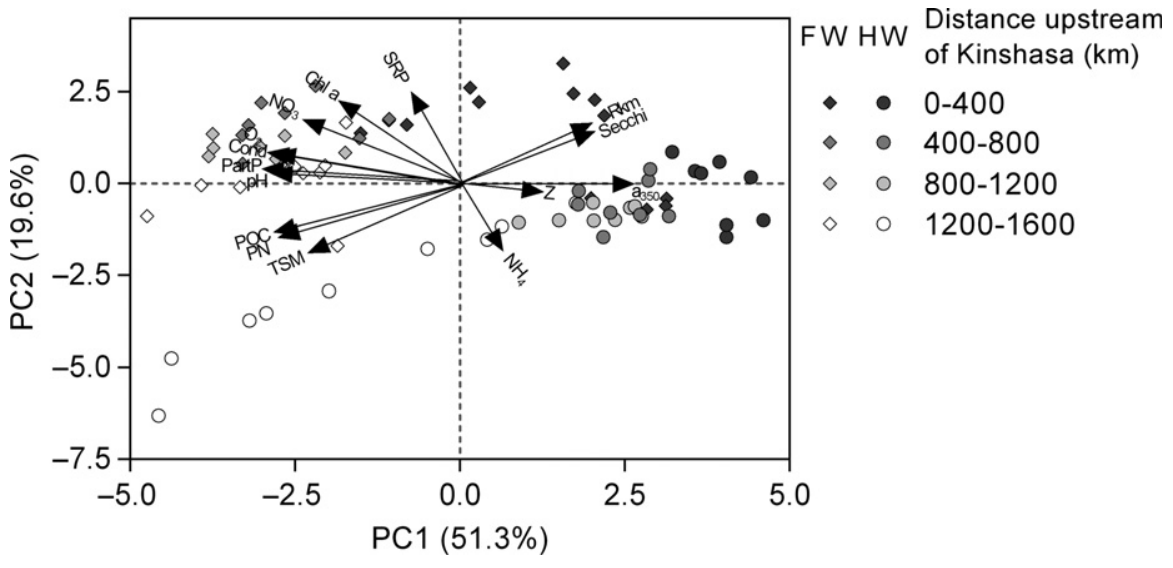




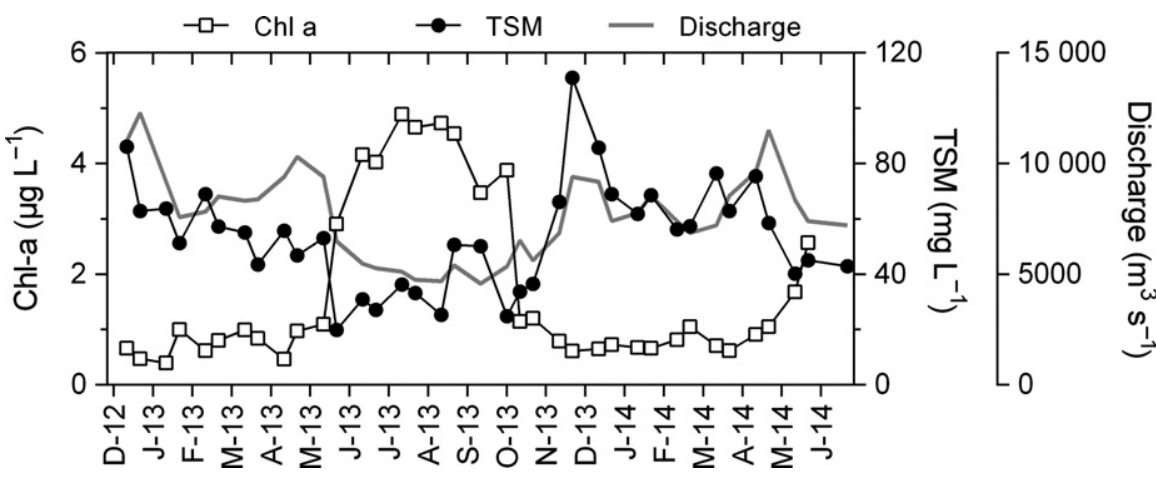

Fig. 8 Variation of discharge $\left(\mathrm{m}^{3} \mathrm{~s}^{-1}\right)$, total suspended matter (TSM, $\mathrm{mg} \mathrm{L}^{-1}$ ) and chlorophyll $a\left(\mu \mathrm{g} \mathrm{L}^{-1}\right)$ in the Congo River at Kisangani between December 2012 and June 2014.

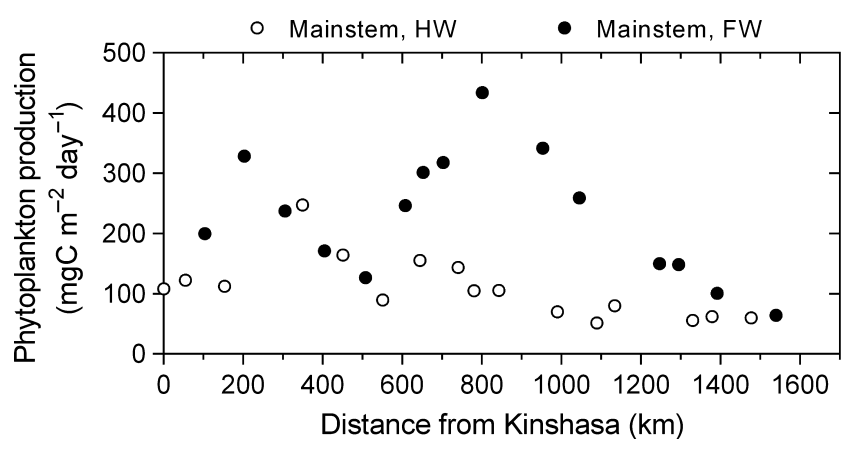

Fig. 9 Longitudinal variation of phytoplankton production ( $\mathrm{mg} \mathrm{C} \mathrm{m}^{-2} \mathrm{day}^{-1}$ ) in the Congo River mainstem during the sampling campaigns of December 2013 (high water, HW) and June 2014 (falling water, FW).

growth rates were comprised between -0.13 and 0.43 day $^{-1}$ in FW and -0.07 and 0.63 day $^{-1}$ in HW.

\section{Discussion}

The results of this study provide evidence of significant phytoplankton production in the main channel in the second largest river of the world, the Congo River. Phytoplankton biomass developed mainly in the period of low water and FW, when the lower discharge (resulting in higher residence time and lower dilution by tributaries) and the lower TSM load allowed sufficient light penetration for substantial primary production to occur. Chl a reached a maximal concentration (up to $c$. $8 \mu \mathrm{g} \mathrm{L}^{-1}$ ) after a gradual increase along a c. 1000-km transect in the FW period, resulting from net phytoplankton increase, most probably allowed by lower dilution by tributaries than in the HW period. In the Congo River, phytoplankton biomass may be controlled by dilution rather than by residence time. Indeed, given the relatively high production rates of the phytoplankton, the river is long enough to allow sufficient residence time for biomass increase, irrespective of the discharge: based on a simple calculation, the water residence time from Kisangani to Kinshasa was c. 25 days in HW, and it did not increase much (c. 30 days) in FW. By contrast, the discharge of all tributaries, estimated from the few data available, was about twice as high in HW than in FW, and the main tributaries contributed a significant proportion of the main river flow. For instance, it could be estimated that the Kasai River, the Oubangui River and the Ruki River contribute, respectively, to 21, 8 and $12 \%$ of the discharge recorded in Kinshasa, whereas the river network located upstream of Kisangani contributes to $20 \%$ of the total river flow. The temporal survey at Kisangani provided further evidence that phytoplankton development was controlled by hydrological factors and turbidity.

In the most downstream section of the Congo River, phytoplankton biomass declined, as a result from combined effects of dilution, TSM inputs by major tributaries (Oubangui and Kasai rivers) and greater channel depth. The region after the confluence of the Kasai also corresponds to a narrowing and deepening of the Congo upstream of Pool Malebo (Runge, 2008; O'Loughlin et al., 2013). Schematically, the longitudinal profile of phytoplankton biomass in the Congo River is, therefore, similar to that described in the early publications on phytoplankton in large temperate rivers (e.g. Welch, 1952): an absence or small amount of true plankton in an upstream section, followed by a downstream increase up to a maximum in a middle section, and decline in the lower section. This similarity clearly stems from the same controlling factor, i.e. hydrology, influencing residence time, dilution during downstream transport and suspended matter loading, which determines the availability of light.

Our ${ }^{13} \mathrm{C}$ uptake measurements and estimates of daily primary production provide evidence for significant phytoplankton production in the mainstem of the Congo River, particularly in shallow sections of the river between 400 and $1400 \mathrm{~km}$ from Kinshasa, where organic $\mathrm{C}$ losses from respiration were reduced, allowing positive net production to take place. The substantial 
phytoplankton production occurring in the main channel may be a major difference between the mainstem of the Congo River and that of most other large tropical rivers. The general pattern in the rivers of South America (e.g. Amazon, Orinoco, Paraná) is that phytoplankton growth is not possible in their mainstem, due to a very low euphotic depth:river depth ratio (e.g. Fisher \& Parsley, 1979), resulting from high TSM loading in a deep river channel. Instead, in the South American floodplains, the bulk of planktonic primary production takes place in lakes that receive nutrients from the river during the 'flood pulse' (Junk et al., 1989) in the rising water period, and most phytoplankton present in the rivers is imported from the lakes. In a similar way, in catchments without extensive seasonally inundated floodplains, natural lakes and man-made reservoirs in the catchment act as reactors where phytoplankton is produced, resulting from improved light penetration from sedimentation of suspended matter, and their overflow provides planktonic algae and cyanobacteria to the downstream river section. As described by Talling \& Prowse (2010), these inocula can be substantial and are transported far downstream, but the maintenance of populations in the river depends on ability to grow in a turbulent, usually turbid, environment with short retention time. However, transport from floodplain lakes and reservoirs is not the only process allowing phytoplankton presence in the main channel of tropical rivers. Studies conducted in tropical rivers have shown that a substantial part of the phytoplankton production can take place in slow-flowing areas of the main channel, as in the Orinoco River (Lewis, 1988) or in the Daly River, tropical Australia (Townsend, Przybylska \& Miloshis, 2012). Moreover, the success of Aulacoseira species, which are abundant in the turbulent and turbid waters of the Paraná river, while being absent from the floodplain lakes ( $\mathrm{O}^{\prime}$ Farrell, Izaguirre \& Vinocur, 1996; Devercelli et al., 2014), suggests that they originate from the river environment rather than being imported from lakes.

In contrast to the Nile and to its South American counterparts, the Congo River has only a few lakes in its catchment and lacks an extensive seasonal floodplain (Borges et al., 2015a). the floodplain consists of permanently flooded forest, with little variation in water depth between the extremes of the hydrograph. A factor explaining the possibility of net phytoplankton growth in the river main channel is the relatively low TSM load over most of the studied transect, compared for instance with the Amazon. Indeed, the average TSM in the Amazon mainstem at Obidos of $230 \mathrm{mg} \mathrm{L}^{-1}$ (range 93$385 \mathrm{mg} \mathrm{L}^{-1}$, Richey et al., 1986) is distinctly higher than the average TSM in the Congo mainstem at Kinshasa of $26 \mathrm{mg} \mathrm{L}^{-1}$ (range 15-40 $\mathrm{mg} \mathrm{L}^{-1}$, Coynel et al., 2005) and at Kisangani of $53 \mathrm{mg} \mathrm{L}^{-1}$ (range $13-111 \mathrm{mg} \mathrm{L}^{-1}$, A.V. Borges, own unpubl. data). Another factor is the low mean depth in most of the Congo River mainstem that allowed a euphotic depth:channel depth ratio favourable for sufficient net photosynthesis to sustain algal growth.

Two different parts can be distinguished in the Kisangani-Kinshasa transect: the upper sector of about $200 \mathrm{~km}$ in length where TSM is higher during the HW period and the whole river downstream of this upper sector, where TSM is actually lower in HW conditions than in FW. This could be explained by deposition of sediments in the 'Cuvette Centrale Congolaise' region during HWs, whereas sediments and nutrients were transported back to the rivers during FWs. Several results of our study point towards this process: higher TSM in most of the river transect and increased inorganic macro-nutrients $\left(\mathrm{NO}_{3}{ }^{-}\right.$and SRP) both in the main river and the tributaries during FW. This nutrient increase might have favoured phytoplankton growth, although there was no clear evidence for a change in phytoplankton nutrient status from elemental ratios. Indeed, POC:PN and POC:PartP ratios cannot be relied on as indicators of the phytoplankton nutrient status, as POC:Chl $a$ ratios were quite high, showing that phytoplankton carbon was a small fraction of the POC (2-8\%, using a Chl $a$ :C ratio of 40; Harris, 1986).

Phytoplankton composition was quite different between HW and at FW. In FW conditions in the mainstem, diatoms contributed on average to $60 \%$ of $\mathrm{Chl} a$ and were the dominant group at all sites, in agreement to what was reported in most studies on tropical river phytoplankton. Accordingly, Hughes et al. (2011) found that the largest fraction of biogenic silica (BSi) in the Congo River was composed of diatoms, with significant uptake of dissolved silicon, affecting its concentration in the river, as well as silicon isotopic fractionation. This confirms that significant diatom production does occur in the Congo River mainstem at falling and probably low waters.

The most abundant taxa were those adapted to low light conditions, such as diverse taxa of Aulacoseira, described as the most competitive at high Si:light ratio (Kilham et al., 1986). The second most important phytoplankton taxa in the FW period were the green algae, which accounted for $10 \%$ of Chl $a$, while the other groups (cyanobacteria and cryptophytes) accounted for $8 \%$ of Chl $a$ on average. In contrast, during HW, green algae contributed to $88 \%$ of $\mathrm{Chl} a$ in the Congo River mainstem conditions, and $87 \%$ in the tributaries, 
12 J.-P. Descy et al.

whereas diatoms barely reached $10 \%$ of total phytoplankton biomass. This is quite different from most reports on phytoplankton composition in large tropical rivers, particularly of South America (e.g. Garcia de Emiliani, 1990; Lewis et al., 1995; Davies et al., 2008; Devercelli et al., 2014; O'Farrell \& Izaguirre, 2014) but also from Africa (Prowse \& Talling, 1958; Talling \& Rzóska, 1967): one would have expected dominance of diatoms during both discharge conditions, owing to light limitation resulting from the TSM concentration in the mainstem and large tributaries, and from high DOC in the blackwater tributaries (Mayora, Devercelli \& Frau, 2016). Indeed, considering a mean daily surface irradiance of $750 \mu \mathrm{E} \mathrm{m}^{-2} \mathrm{~s}^{-1}$, calculated from continuous recordings during the cruises, the mean light exposure of phytoplankton would have been on average $35 \mu \mathrm{E} \mathrm{m}^{-2} \mathrm{~s}^{-1}$ in $\mathrm{FW}$ versus $71 \mu \mathrm{E} \mathrm{m}^{-2} \mathrm{~s}^{-1}$ in $\mathrm{HW}$ (Table 1). Under such conditions, diatoms, which are highly efficient at photosynthesis at low light (Kilham et al., 1986; Kirk, 1994), would have been able to grow, so that the most likely explanation for their lack of development at HW is dilution by water inputs and lack of time to build populations in the fast-flowing mainstem. In contrast, green algae typically need high light for growth: Dauta (1982) measured optimal light for photosynthesis $\left(I_{\mathrm{opt}}\right)$ at different temperatures for some coccal green taxa and found $I_{\mathrm{opt}}$ values between 180 and $281 \mu \mathrm{E} \mathrm{m}^{-2} \mathrm{~s}^{-1}$ in the $25-30{ }^{\circ} \mathrm{C}$ range. The question thus arises how did green algae manage to maintain significant populations during HW. The most likely mechanism by which they can access these light levels and achieve high growth rates may be that they grew in the well-developed littoral/wetland aquatic vegetation of the main river, thereby providing inocula to the mainstem. This hypothesis, suggested by the presence and high abundance of green algae in a sample taken at HW in the fringing aquatic meadow, should be further substantiated by specific observations. The general descriptions of the ecology and distribution of key coccal and filamentous conjugate genera found in the Congo River show their belonging to the metaphyton, that is, algae loosely attached to the submerged macrophytes, from which they may be dislodged by the waves and current and then occur as tychoplankters in open waters (e.g. Behre, 1956; John et al. 2011). In these shallow environments, green algae may have benefited from adequate light conditions for growth, and water exchanges with the main channel may have supplied cells to the mainstem, according to the process described by Reynolds et al. (1991) involving the hydrological 'dead zones'. Similarly, the observations of
Stoyneva (1994) suggest the role of macrophytes growing in the shallow river margin for sustaining the planktonic green algae in the Danube River. Once in the mainstem, green algae may have been able to maintain populations, provided that they were able to sustain a high photosynthetic rate. More research would be needed to assess whether plankton retention in the fringing aquatic vegetation actually plays a role in the maintenance of phytoplankton production in the mainstem of the Congo River during the different hydrological periods.

The fact that phytoplankton production occurs in the Congo River mainstem is of some biogeochemical significance, such as the effect of diatom silicon uptake on the Si cycle (Hughes et al., 2011), but this production remains marginal in terms of the overall river network carbon budget. For instance, the emission of $\mathrm{CO}_{2}$ to the atmosphere from the Congo River fuelled by processing of organic matter from land and wetland (13 800$18250 \mathrm{mg} \mathrm{C} \mathrm{m}^{-2}$ day $^{-1}$, Borges et al., 2015b) is two orders of magnitude higher than primary production ( $<500 \mathrm{mg} \mathrm{C} \mathrm{m}^{-2}$ day $\left.^{-1}\right)$. The major contribution of phytoplankton primary production and biomass may lie in its role in sustaining the food web. Indeed, as for the Amazon River (Forsberg et al., 1993) where a key role of autochthonous $\mathrm{C}$ production by phytoplankton in fish diet was evidenced, there are indications that phytoplankton is an important component of the diet of some fish species in the Congo River. This is the case, based on gut content analysis, in two cyprinid species (Pwema et al., 2015) and in a catfish (Tembeni Makiadi et al., 2013) in the Malebo pool. This stresses the importance of understanding food-web processes, and in particular, the role of allochthonous versus autochthonous $\mathrm{C}$, in large tropical rivers, where the fisheries contribute to the local economies and provide food for the human populations.

\section{Acknowledgments}

This study was funded by the European Research Council (ERC-StG 240002 AFRIVAL), the Fonds National de la Recherche Scientifique (FNRS, TransCongo, 14711103), the Belgian Federal Science Policy (BELSPO, COBAFISH, SD/AR/05A), the Research Foundation Flanders (FWOVlaanderen), the Research Council of the KU Leuven and the Fonds Léopold III pour l'Exploration et la Conservation de la Nature. The freshwater discharge data of the Congo at Kinshasa were kindly provided by the Régie des Voies Fluviales (RVF, DRC). We are grateful for help in sampling from T. Mambo Baba, E. Tambwe 
Lukosha and A. Toengaho (Université de Kisangani, DRC) and for analytical support from S. Petrovic (University of Liège), B. Leporcq (University of Namur), and Zita Kelemen and Cédric Morana (KU Leuven). Identification of some diatoms was checked by Priscila Tremarin (Universidade Federal do Paraná, Curitiba, Brazil). TL and AVB are a postdoctoral researcher and senior research associate, respectively, at the FNRS. The complete dataset is available on request. We thank an anonymous reviewer and William Lewis for helping improve the article.

\section{References}

Abril G., Martinez J.M., Artigas L.F., Moreira-Turcq P., Benedetti M.F., Vidal L. et al. (2014) Amazon River carbon dioxide outgassing fuelled by wetlands. Nature, 505, 395-398.

American Public Health Association (1998) Standard Methods for the Examination of Water and Wastewater. Washington, D.C: APHA-AWWA-WEF.

Araújo-Lima C.A.R.M., Forsberg B.R., Victoria R. \& Martinelli L. (1986) Energy sources for detritivorous fishes in the Amazon. Science, 234, 1256-1258.

Basu B.K. \& Pick F.R. (1996) Factors regulating phytoplankton and zooplankton biomass in temperate rivers. Limnology and Oceanography, 41, 1572-1577.

Behre K. (1956) Die Algenbesiedlung Seen um Bremen und Bremerhaven. Veröffentlichungen des Instituts für Meeresforschung in Bremerhaven, 4, 221-383.

Benedito-Cecilio E., Araújo-Lima C.A.R.M., Forsberg B.R. \& Bittencourt M.M. (2000) Carbon sources of Amazonian fisheries. Fisheries Management and Ecology, 7, 305-315.

Bonetto C.A. (1983) Fitoplancton y producción primaria del Paraná Medio. Ecosur, 10, 79-102.

Borcard D., Gillet F. \& Legendre P. (2011) Numerical Ecology with R. Springer, New York.

Borges A.V., Abril G., Darchambeau F., Teodoru C.R., Deborde J., Vidal L.O. et al. (2015a) Divergent biophysical controls of aquatic $\mathrm{CO}_{2}$ and $\mathrm{CH}_{4}$ in the World's two largest rivers. Scientific Reports, 5, 15614. doi:10.1038/srep15614.

Borges A.V., Darchambeau F., Teodoru C.R., Marwick T.R., Tamooh F., Geeraert N. et al. (2015b) Globally significant greenhouse gas emissions from African inland waters. Nature Geoscience, 8, 637-642.

Bouillon S., Yambélé A., Spencer R.G.M., Gillikin D.P., Hernes P.J., Six J. et al. (2012) Organic matter sources, fluxes and greenhouse gas exchange in the Oubangui River (Congo River basin). Biogeosciences, 9, 2045-2062.

Bwangoy J.-R.B., Hansen M.C., Roy D.P., De Grandi G. \& Justice C.O. (2010) Wetland mapping in the Congo Basin using optical and radar remotely sensed data and derived topographical indices. Remote Sensing of the Environment, 114, 73-86.
Coynel A., Seyler P., Etcheber H., Meybeck M. \& Orange D. (2005) Spatial and seasonal dynamics of total suspended sediment and organic carbon species in the Congo River. Global Biogeochemical Cycles, 19, GB4019. doi:10.1029/ 2004 GB002335.

Dauchez S., Legendre L. \& Fortier L. (1995) Assessment of simultaneous uptake of nitrogenous nutrients $\left({ }^{15} \mathrm{~N}\right)$ and inorganic carbon $\left({ }^{13} \mathrm{C}\right)$ by natural phytoplankton populations. Marine Biology, 123, 651-666.

Dauta A. (1982) Conditions de développement du phytoplancton. Etude comparative du comportement de huit espèces en culture. I. Détermination des paramètres de croissance en fonction de la lumière et de la température. Annales de Limnologie, 18, 217-262.

Davies P.M. Jr, Bunn S.E. Jr \& Hamilton S.K. Jr (2008) Primary production in tropical streams and rivers. In: Tropical Stream Ecology (Ed. D. Dudgeon), pp. 23-42. Academic Press, London.

Descy J.-P., Hardy M.-A., Sténuite S., Pirlot S., Leporcq B., Kimirei I. et al. (2005) Phytoplankton pigments and community composition in Lake Tanganyika. Freshwater Biology, 50, 668-684.

Descy J.-P., Servais P., Smitz J.S., Billen G. \& Everbecq E. (1987) Phytoplankton biomass and production in the river Meuse (Belgium). Water Research, 21, 1557-1566.

Devercelli M., De Domitrovic Y.Z., Forastier M.E. \& De Zaburlín N.M. (2014) Phytoplankton of the Paraná River Basin. In: Freshwater Phytoplankton of Argentina. Advances in Limnology, 65, 39-65.

Fisher T.R. \& Parsley P.E. (1979) Amazon lakes: water storage and nutrient stripping by algae. Limnology and Oceanography, 24, 547-553.

Forsberg B.R., Araújo-Lima C.A.R.M., Martinelli L.A., Victoria R.L. \& Bonassi J.A. (1993) Autotrophic carbon sources for fish of the central Amazon. Ecology, 74, 643-652. doi: $10.2307 / 1940793$.

Garcia de Emiliani M.O. (1990) Phytoplankton ecology of Middle Paraná River. Acta Limnologica Brasiliana, 3, 391417.

Hama T., Miyazaki T., Ogawa Y., Iwakuma T., Takahashi M., Otsuki A. et al. (1983) Measurement of photosynthetic production of a marine phytoplankton population using a stable ${ }^{13} \mathrm{C}$ isotope. Marine Biology, 73, 31-36.

Harris G.P. (1986) Phytoplankton Ecology. Structure, Function and Fluctuation. Chapman and Hall, Cambridge.

Hötzel G. \& Croome R. (1996) Population dynamics of Aulacoseira granulata (Ehr) Simonsen (Bacillariophyceae, Centrales), the dominant alga in the Murray River, Australia. Archiv für Hydrobiologie, 136, 191-215.

Hughes H.J., Sondag F., Cocquyt C., Laraque A., Pandi A., André L. \& Cardinal D. (2011) Effect of seasonal biogenic silica variations on dissolved silicon fluxes and isotopic signatures in the Congo River. Limnology and Oceanography, 56, 551-561. 
Iltis A. (1982) Peuplements algaux des rivières de Côte d'Ivoire: 2. Variations saisonnières des biovolumes, de la composition et de la diversité spécifique. Revue d'Hydrobiologie Tropicale, 15, 241-251.

Imevbore A.M.A. (1970) The chemistry of the River Niger in the Kainji reservoir area. Archiv für Hydrobiologie, 67, 412-431.

Imevbore A.M.A. \& Visser S.A. (1969) A study of microbiological and chemical stratification of the Niger River within the future Kainji Lake area. In: Man-Made Lakes: the Accra Symposium (Ed. L.E. Obeng), pp. 94-102, Ghana University Press, Accra.

John D.M., Whitton B.A. \& Brook A.J. (2011) The Freshwater Algal Flora of the British Isles. An Identification Guide to Freshwater and Terrestrial Algae, 2nd edn. Cambridge University Press, Cambridge.

Junk W.J., Bayley P.B. \& Sparks R.E. (1989) The flood pulse concept in river-floodplain systems. In: Proceedings of the International Large River Symposium (Ed. D.P. Dodge). Canadian Special Publication of Fisheries and Aquatic Sciences, 106, 110-127.

Kilham P., Kilham S.S. \& Hecky R.E. (1986) Hypothesized resource relationships among African planktonic diatoms. Limnology and Oceanography, 31, 1169-1181.

Kirk J.T.O. (1994) Light and Photosynthesis in Aquatic Ecosystems, 2nd edn. Cambridge University Press, Cambridge.

Koné Y.J.M., Abril G., Kouadio K.N., Delille B. \& Borges A.V. (2009) Seasonal variability of carbon dioxide in the rivers and lagoons of Ivory Coast (West Africa). Estuaries and Coasts, 32, 246-260.

Lambert T., Bouillon S., Darchambeau F., Massicotte P. \& Borges A.V. (2016) Shift in the chemical composition of dissolved organic matter in the Congo River network. Biogeosciences, 13, 5405-5420.

Lambert T., Darchambeau F., Bouillon S., Alhou B., Mbega J.-D., Teodoru C.R. et al. (2015) Landscape control on the spatial and temporal variability of chromophoric dissolved organic matter and dissolved organic carbon in large African rivers. Ecosystems, 18, 1224-1239. doi:10.1007/s10021-015-9894-5.

Legendre L. \& Gosselin M. (1996) Estimation of $\mathrm{N}$ or C uptake rates by phytoplankton using ${ }^{15} \mathrm{~N}$ or ${ }^{13} \mathrm{C}$ : revisiting the usual computation formulae. Journal of Plankton Research, 19, 263-271.

Lewis W.M. Jr (1988) Primary production in the Orinoco River. Ecology, 69, 679-692.

Lewis W.M. Jr, Hamilton S.K. \& Saunders J.F. (1995) Rivers of northern South America. In: River and Stream Ecosystems (Eds C.E. Cushing, K.W. Cummins \& G.W. Minshall), pp. 219-256. Elsevier Science B.V, Amsterdam.

López-Sandoval D.C., Rodríguez-Ramos T., Cermeño P., Sobrino C. \& Marañón E. (2014) Photosynthesis and respiration in marine phytoplankton: Relationship with cell size, taxonomic affiliation, and growth phase. Journal of Experimental Marine Biology and Ecology, 457, 151-159.
Mackey M.D., Mackey D.J., Higgins H.W. \& Wright S.W. (1996) CHEMTAX - a program for estimating class abundances from chemical markers: application to HPLC measurements of phytoplankton. Marine Ecology Progress Series, 144, 265-283.

Mayora G., Devercelli M. \& Frau D. (2016) Spatial variability of chromophoric dissolved organic matter in a large floodplain river: control factors and relations with phytoplankton during a low water period. Ecohydrology, 9, 487497.

Melack J.M. \& Forsberg B.R. (2001) Biogeochemistry of Amazon floodplain lakes and associated wetlands. In: The Biogeochemistry of the Amazon Basin and Its Role in a Changing World (Eds M.E. McClain, R.L. Victoria \& J.E. Richey), pp. 235-276. Oxford University Press, Oxford.

Minaudo C., Meybeck M., Moatar F., Gassama N. \& Curie F. (2015) Eutrophication mitigation in rivers: 30 years of trends in spatial and seasonal patterns of biogeochemistry of the Loire River (1980-2012). Biogeosciences, 12, 2549-2563.

Neiff J.J. (1996) Large rivers of South America: toward the new approach. Verhandlungen Internationale Vereinigung für Theoretische und Angewandte Limnologie, 26, 167-180.

O'Farrell I. \& Izaguirre I. (2014) Phytoplankton of the middle and lower stretches of the Uruguay River. In: Freshwater Phytoplankton of Argentina. Advances in Limnology, 65, 113-126.

O'Farrell I., Izaguirre I \& Vinocur A. (1996). Phytoplankton ecology of the Lower Paraná River. Archiv für Hydrobiologie, Large Rivers, 11 (Suppl. 115), 75-89.

O'Loughlin F., Trigg M.A., Schumann G.J.-P. \& Bates P.D. (2013) Hydraulic characterization of the middle reach of the Congo River. Water Resources Research, 49, 5059-5070. doi:10.1002/wrcr.20398.

Ouffoue K.S., Salla M., Kicho D.Y., Soro D., Da K.P. \& Tonzibo Z.F. (2013) Water Quality Assessment of the Coastal Tropical River'Sboubo (Côte d'Ivoire): physicochemical and biological aspects. Journal of Environment Pollution and Human Health, 1, 9-15.

Prowse G.A. \& Talling J.F. (1958) The seasonal growth and succession of plankton algae in the White Nile. Limnology E Oceanography, 3, 222-238.

Pwema V., Mbomba N.B., Takoy A.L., Malekani J.M. \& Micha J.-C. (2015) Comparison of the diet of two species of Labeo (Cyprinidae): a rheophilic one, Labeo sorex and a limnophilic one, Labeo lineatus in the Malebo pool (Congo River). Congo Sciences, 3, 24-30.

$\mathrm{R}$ Development Core Team R (2008) R: A Language and Environment for Statistical Computing. R Foundation for Statistical Computing, Vienna. Available at: http:// www.R-project.org/.

Reynolds C.S. (1984) The Ecology of Freshwater Phytoplankton. Cambridge University Press, Cambridge.

Reynolds C.S. (1988) Potamoplankton: paradigms, paradoxes and prognoses. In: Algae and Aquatic Environment. 
Contributions in Honour of J. W. G. Lund (Ed. F.E. Round), pp. 285-325. Biopress Ltd, Bristol.

Reynolds C.S. (1994) The long, the short and the stalled: on the attributes of phytoplankton selected by physical mixing in lakes and rivers. Hydrobiologia, 289, 9-21.

Reynolds C.S. (2006) Ecology of phytoplankton, p. 535. Cambridge University Press, Cambridge.

Reynolds C.S., Carling P.A. \& Beven K. (1991) Flow in river channels: new insights into hydraulic retention. Archiv für Hydrobiologie, 121, 171-179.

Reynolds C.S. \& Descy J.-P. (1996) The production, biomass and structure of phytoplankton in large rivers. Archiv für Hydrobiologie Beiheft 113, Large Rivers, 10, 161-187.

Richey J.E., Meade R.H., Salati E., Devol A.H., Nordin C.F. Jr \& Dos Santos U. (1986) Water discharge and suspended sediment concentrations in the Amazon River: 1982-1984. Water Resources Research, 22, 756-764.

Riley G.A. (1957) Phytoplankton of the north central Sargasso Sea. Limnology and Oceanography, 2, 252-270.

Rojo C., Alvarez-Cobelas M. \& Arauzo M. (1994) An elementary, structural analysis of river phytoplankton. Hydrobiologia, 289, 43-55.

Runge J. (2008) The Congo River, Central Africa. In: Large Rivers: Geomorphology and Management (Ed. A. Gupta), pp. 293-309. John Wiley \& Sons, Hoboken, New Jersey.

Stoyneva M.P. (1994) Shallows of the lower Danube as additional sources of potamoplankton. Hydrobiologia, 289, 171-178.

Talling J.F. \& Prowse G.A. (2010) Selective recruitment and resurgence of tropical river phytoplankton: evidence from the Nile system of lakes, rivers, reservoirs and ponds. Hydrobiologia, 637, 187-195.

Talling J.F. \& Rzóska J. (1967) The development of plankton in relation to hydrological regime in the Blue Nile. Journal of Ecology, 55, 637-662.

Tamooh F., Van den Meersche K., Meysman F., Marwick T.R., Borges A.V., Merckx R. et al. (2012) Distribution and origin of suspended matter and organic carbon pools in the Tana River Basin, Kenya. Biogeosciences, 9, 2905-2920.

Tembeni Makiadi J., Mbomba Nseu B., Micha J.-C. \& Vandewalle P. (2013) Feeding ecology of the african suckermouth catfish Euchilichthys guentheri (Mochokidae, siluriformes) of Malebo Pool, Congo River (Democratic Republic of Congo). Revue d'Ecologie (La Terre et la Vie), 68, 291-304.

Townsend S.A., Przybylska M. \& Miloshis M. (2012) Phytoplankton composition and constraints to biomass in the middle reaches of an Australian tropical river during base flow. Marine and Freshwater Research, 63, 48-59.

Valderrama J.C. (1981) The simultaneous analysis of total nitrogen and total phosphorus in natural waters. Marine Chemistry, 10, 109-122.
Vasquez E. \& Wilbert W. (1992) The Orinoco: physical, biological and cultural diversity of a major tropical alluvial river. In: The Rivers Handbook, Vol. 1 (Eds E. Petts \& P. Calow), pp. 448-471. Blackwell Scientific Publications, Oxford.

Vollenweider R.A. (1965) Calculations models of photosynthesis-depth curves and some implications regarding day rate estimates in primary production measurements. Memorie dell'Istituto Italiano di Idrobiologia, 18, 425-457.

Welch E.B. (1952) Limnology, 2nd edn. Mc Graw-Hill, New York.

Westwood D. (1981) Ammonia in waters. In: Methods for the Examination of Waters and Associated Materials. Standing committee of Analysts, London.

Wissmar R.C., Richey J.E., Stallard R.F. \& Edmond J.M. (1981) Plankton metabolism and carbon processes in the Amazon River, its tributaries, and floodplain waters, Peru-Brazil, May-June 1977. Ecology, 62, 1622-1633.

Wright S.W. \& Jeffrey S.W. (2006) Pigment markers for phytoplankton production. In: Marine Organic Matter: Biomarkers, Isotopes and DNA, Vol. 2 (Ed. J.K. Volkman), pp. 71-104. Springer, Berlin.

Zalocar De Domitrovic Y. (2002) Structure and variation of the Paraguay River phytoplankton in two periods of its hydrological cycle. Hydrobiologia, 472, 177-196.

Zalocar de Domitrovic Y., Devercelli M. \& Garcia de Emiliani M.O. (2007) Phytoplankton. In: The Middle Paraná River. Limnology of a Subtropical Wetland (Eds M.H. Iriondo, J.C. Paggi \& M.J. Parma), pp. 177-204. Springer, Berlin.

Zalocar de Domitrovic Y., Devercelli M. \& Forastier M. E. (2014) Phytoplankton of the Paraguay and Bermejo rivers. In: Freshwater Phytoplankton of Argentina. Advances in Limnology, 65, 67-80.

\section{Supporting Information}

Additional Supporting Information may be found in the online version of this article:

Figure S1. Results of a principal component analysis carried out on the physical and chemical data in the Congo River mainstem and its tributaries, from the sampling campaigns of December 2013 (high water, HW) and June 2014 (falling water, FW). The dots are the sampling sites; their shading depends on the distances from Kinshasa. See Table 1 for acronyms.

(Manuscript accepted 12 September 2016) 